\title{
Examination of the Relationship between the Democratic Attitude of Prospective Teachers and Their Communication Skills
}

\author{
Ayşe Mentiş Taş \\ Ahmet Keleşoğlu Faculty of Education, Necmettin Erbakan University, Turkey
}

Copyright $\bigcirc 2018$ by authors, all rights reserved. Authors agree that this article remains permanently open access under the terms of the Creative Commons Attribution License 4.0 International License

\begin{abstract}
In this study, the relationship between the democratic attitude of prospective teachers and their communication skills was examined. It was researched if there is a significant difference between the prospective teachers' democratic attitude and communication skills depending on the factors of gender and subject of license (the area that they specialize in). The research was designed in relational screening model. The population of the study was the prospective teacher students in Necmettin Erbakan University Ahmet Keleşoğlu Faculty of Education. 336 prospective teachers were chosen within this population as the research sample. "Democratic Attitude Scale" and Communication Skills Inventory were used to collect data. Data were analyzed with single factorial MANOVA. It was found that there is a significant positive correlation at a low level between the communication skills and democratic attitude of prospective teachers. It was determined that there is no significant difference depending on gender neither for the scores of democratic attitudes nor for the scores of the communication skills of prospective teachers. It was found that there is a significant difference between communication scores of prospective teachers depending on their subject of license (the area that they specialize). It was found that the subject of license variable has a medium level of correlation on the communication skills of prospective teachers. On the other hand, it was found that subject of the license has no significant correlation on the democratic attitude scores.
\end{abstract}

Keywords Democratic Attitude, Communication Skills, Prospective Teacher

\section{Introduction}

Democracy is a Latin concept. It is derived from two words: "Demos" meaning "People" and "Katos" meaning "Power". In sciences of law an politics, democracy corresponds to political regimes and governments where the political power is based on people, the authority of sovereignty belongs to the people and the people govern themselves. The understanding of the sovereignty of people, election of power by people and acting of power in line with the people's will underlie the concept of democracy [1].In the political model qualified as democracy, there should be three fundamental criteria; general and equal vote, free and fair elections, constitutional assurance of fundamental rights and freedoms [2].

The meanings attributed to the term of democracy have varied during the last half-century. Self-government, government of people's representatives, government of people's party, majority rule, proletarian dictatorship, maximum political participation, multi-party system, political and social pluralism, equal civil rights, civil and political liberties, free society, civil society are only some of the meanings attributed to the term of democracy. Actually, the concept of democracy has a core meaning. Democracy is a decision-making style where binding rules and policies are determined under the control of people. An order which provides equal and direct participation right in this decision-making mechanism to all members of the society is also qualified as a democratic order. In other words, in order for a political order to be qualified as democratic, it has to carry the principles of public inspection and political equality into effect at the highest level possible[3].

Two opposite and incompatible understandings of democracy have emerged on the path of democracy to achieve its purpose. One of them is Western pluralistic democracy while the other is Marxist-Socialist democracy. Fundamental principles of pluralistic democracy are based on political pluralism, representation, election, majority's right to govern, freedom to oppose, protection of 
fundamental rights and freedoms and equality before the law. The most distinct feature of Marxist democracy is basing on a single ideology. In Marxist democracy, the power is the enforcer of Marxism ideology. It is not pluralistic and dialogist. Communist party is in the power. There is no other party. In classic pluralistic democracy, on the other hand, it is important to glorify the individuals and make them free. What's important in Marxist ideology is not liberty but liberating the people. In order to liberate the society, liberation of the individual that underlies the classic pluralistic democracies may be restricted. Because liberation of individual and liberation of society are not the same thing in Marxism. Unexpected collapse of Marxist democracy in a short period of time led to transition to pluralistic democracy in some countries governed by Marxist democracy. For example, Russia has filled the void that emerged after the collapse of Soviet Union. The regime that bases on pluralistic democracy became effective [1].

Democracy is a regime where it is reconciled on the method of making decisions related to the public. And the method is formalized in the form of "will of the majority". However, the relationship between majority and minority requires the availability of some fundamental principles related to the content of decisions made (laws). This is related to the qualifications of democratic governments. It means the democratic regimes also to be a model which is based on human rights and where the superiority of law is dominant. Democracies should be "restricted governments" but not dictatorships of the majority. What restricts the government are fundamental rights and freedoms of citizens. Citizens, the rights of whom should be protected are not only the followers but all the people including the opponents. This reminds us that democracies are not the government of "unity" but a rule of plurality. Plurality means the availability of opposition in a political sense. It is impossible to mention democracy without the opposition that can criticize the government, try to obtain mass support and freely race in elections [2].

In order for democracy continue it's existence and maintain it's prestige, individuals having democratic awareness should be raised. Democracy can only survive "by being a strong democracy secured by competent and responsible citizens."[4].Democracy should be considered as just a way of government. Because democracy is not just a way of government but a philosophy of life and lifestyle. Respect to human dignity and belief in the value of human personality as an individual underlie democratic life and philosophy. This necessitates the provision of an opportunity to develop his/her potentialities and talents to every individual in the society, employment of every individual for occupations appropriate for his/her potential and areas of interest to maintain his/her life and allowance of individuals to have a saying in sealing his/her fate. This means that regulations regarding equality of opportunity and liberty should be made and this is only possible in democracies[5]. Our democratic attitudes determine the level of democracy in our lives. In developing a democratic attitude, the community we live in, the family and the school have a very important place.

Democracy cannot be learned without experiencing it. If the individuals cannot find the medium in their personal and social lives to experience and practice the values and principles, which are tried to be taught in the name of democracy, it's not possible to expect them to become truly democratic people [6].

Democratic attitudes, democratic thinking, etc., first of all, develop in the family and society medium in which the beliefs and attitudes of individuals develop informally. Later democratic values and attitudes gained in the family are developed by teachers who have adopted and internalized democratic values and who are working in schools which are the formal educational institutions [7].

Democracy education in the school constitutes a conceptual and theoretical aspect of the matter. In order to get the desired outcome from the education of democracy, it is necessary for the education and training activities to be carried out according to democratic principles, as well as manifest itself in the teachers' in-class and out-of-class behavior [8].

Democratic class environments influence the student in a positive way and contribute to them in the acquirement of democratic attitudes and behavior. Students who are actively involved in the learning process, who take responsibility and express their opinions comfortably, learn more meaningfully [9].The democratic class environment is, at the same time, a democratic communication medium. Talking about the teaching and learning process in the class also means talking about the communication process. Educational activities, that serve to enable an individual to become an active member of the community in which he or she lives and to adapt to social life, are conducted in a medium of communication. Informal education which starts in the family and the close circle of people where the individual is born as well as formal education which is carried out in a planned and programmed form in educational institutions cannot be considered independently from communication [10].Therefore, it can be said that there is a strong correlation between the quality of communication between the teacher and the student and the success in education and that one of the most important variables on learning is communication skills [11].

The communication environment that the teacher creates with his students is very important both in terms of individualization process and developing independent thinking habit. A successful communication process, by providing a positive contribution to the formation of the student's consciousness of the ego, as well as to the acquirement of independent thinking habit of students, is an important process in terms of cultivating generations, who can discuss and compromise, which is a major 
requirement of a strong democracy. A democratic teacher should not view his communication with the students merely as a process of teaching and learning. Communication in the class environment has more importance than just being a learning and teaching activity; it has very important functions such as providing a positive contribution to the development of the student's self-awareness, to the awareness of the student about his value as an individual being and, as a natural extension of this process, to the development of independent thinking [12]. Consequently, it can be stated that there is a correlation between the democratic attitude of the teachers and communication skills.

When the studies on this subject in Turkey has been searched, it was found that there was research on determining the democratic attitudes or communication skills of teachers or prospective teachers $[13,14,8,15,16$, $11,17,18,19,20,21,22,23,24,25]$ however there was only one research on the relationship of the two. Only a master thesis conducted by [26] on "The examination of the correlation between the communication skills and democratic attitudes of creative drama instructors" was found. As a result, it can be concluded that there is very limited research conducted on this subject. In this context, the subject of this study is chosen to be the correlation of democratic attitudes and communication skills of prospective teachers.

\subsection{Statement of the Problem}

The problem statement of the research is the Examination of the Relationship between Democratic Approaches of Prospective Teachers and Their Communication Skills.

\subsection{The sub-problems}

1- Is there a significant correlation between the democratic attitudes and communication skills of prospective teachers?

2- Is there a significant correlation between the democratic attitudes and communication skills of prospective teachers depending on the factor of gender?

3- Is there a significant correlation between the democratic attitudes and communication skills of prospective teachers depending on the factor of the subject of license (the area that they specialize in)?

\section{Method}

\subsection{Research Model}

The research was designed in relational screening model. The research which was conducted to determine the relations between two or more variables are relational screening models [27].

\subsection{Population and Sample}

The population of the study was the prospective teacher students in Necmettin Erbakan University Ahmet Keleşoğlu Faculty of Education. 336 prospective teachers were chosen within this population as the research sample. The sample consists of prospective teachers who are students in the final year of the following areas; 133 class teachers, 76 pre-school teachers, 66 social science teachers, and 61 science teachers.

\subsection{Data Collection Tools}

\subsubsection{The Scale of Democratic Attitude}

In this research, the "Democratic Attitude Scale", which is designed by the "Published for the Attitude Research Laboratory" and named "Teacher Opinionaire on Democracy", is used. It was adapted to Turkish [28] and its validity and reliability were tested. The democratic attitude scale, which has a one-dimensional structure, consists of 50 items with 32 positive and 18 negative expressions. The total points on the scale are 50. As the scale score gets closer to 50 , it shows that the teachers have a more positive democratic attitude; if the score falls below 20, it shows that the teachers may have an undemocratic attitude. Cronbach's alpha reliability coefficient of the scale is $\alpha=0.87$.

\subsubsection{Communication Skills Inventory}

In this research, The Communication Skills Inventory developed by [29] is used. It is a Likert-type scale comprised of 45 questions with three sub-dimensions as Mental, Emotional, and Behavioral. There are 15 questions in each sub-dimension. Reliability study with two-tailed - test was conducted and the two-tailed reliability coefficient was calculated as; $r=68$. To determine the consistency of the method, the Cronbach Alpha reliability coefficient used was determined as 72 . The correlations of each sub-dimension with the total communication skills are respectively, 83,73 and 82 . The reliability coefficient of the scale was determined as 70 .

\subsection{Data Analysis}

Data have been analyzed by single-factor MANOVA. First of all, it was analyzed whether there are missing data and extreme values. Eight data are not included in the analysis due to being extreme values. Then the assumptions were tested. Subsequently, the "skewness and kurtosis" values of the data were examined to evaluate whether the data showed normal distribution and it was determined that the assumption of normal distribution is verified. When the scatter diagram and the correlations between the dependent variables are examined, it can be concluded that there is a direct correlation between these variables. 


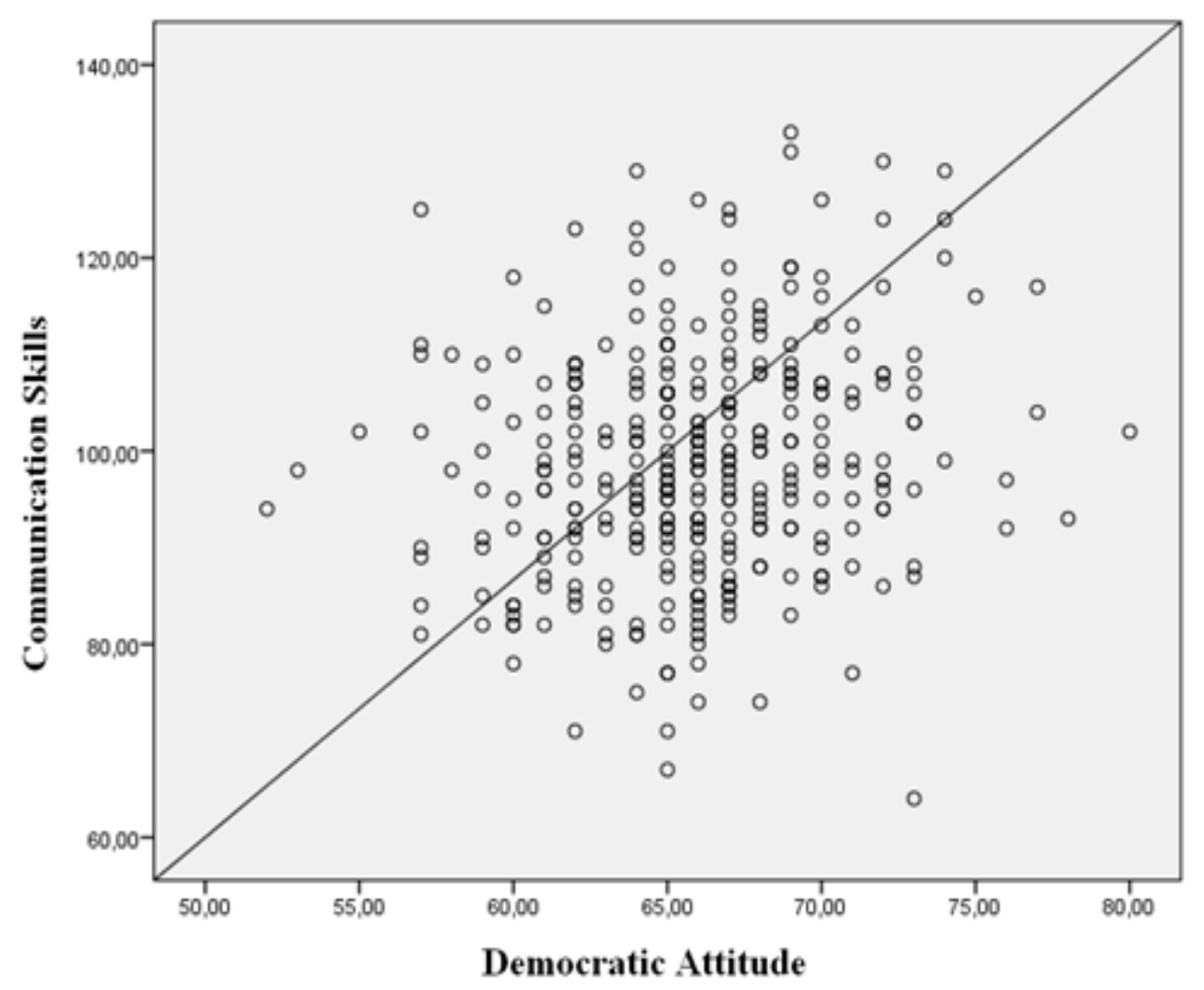

Figure 1. Scatter Diagram

Table 1. Descriptive Statistics

\begin{tabular}{|c|c|c|c|c|c|c|c|}
\hline & $\mathrm{N}$ & $\bar{X}$ & Std. Deviation & Skewness & Kurtosis & Minimum Value & $\begin{array}{c}\text { Maximum } \\
\text { Value }\end{array}$ \\
\hline Communication Skill & 336 & 98.71 & 11.93 & 0.211 & 0.109 & 64.00 & 133.00 \\
\hline Democratic attitude & 336 & 65.91 & 4.22 & 0.016 & 0.583 & 52.00 & 80.00 \\
\hline
\end{tabular}

\section{Findings}

How are the communication skills and level of democratic attitudes of the prospective teachers?

When Table 1 is examined, it can be seen that the mean of the communication skill scores of the prospective teachers is $\bar{X}=98.71$, the mean of democratic attitude scores is $\bar{X}=65.91$. When the medium scores of the scale and the mean scores are compared, it can be concluded that both the communication skills and the democratic attitude scores of the prospective teachers are low. When the coefficients of skewness and kurtosis are examined, it is seen that these values are between -1 and +1 . Based on these results, it can be concluded that communication skills scores and democratic attitude scores do not show excessive deviation from normal distribution.

The research problem 1: Is there a significant correlation between the democratic attitudes and communication skills of prospective teachers?
Table 2. Correlation Coefficients Between Variables

\begin{tabular}{|cc|c|c|}
\hline & & $\begin{array}{c}\text { Communication } \\
\text { Skill }\end{array}$ & $\begin{array}{c}\text { Democratic } \\
\text { attitude }\end{array}$ \\
\hline Communication Skill & $\mathrm{R}$ & 1 & $0.176^{* *}$ \\
\hline Democratic attitude & $\mathrm{r}$ & $0.176^{* *}$ & 1 \\
\hline
\end{tabular}

When Table 2 is examined, it is found that there is a significant positive correlation at a low level between the communication skills and democratic attitude of prospective teachers $(\mathrm{r}=0.176, \mathrm{p}<0.01)$.

The problem Statement 2: Is there a significant difference depending on gender?

Table 3. Descriptive Statistics based on Gender Variable

\begin{tabular}{|ccccccc|}
\hline & \multirow{2}{*}{ Gender } & \multirow{2}{*}{$\mathrm{N}$} & $\bar{X}$ & \multicolumn{2}{c}{ Std. } & \multicolumn{2}{c|}{ Minimum Maximum } \\
& & & Deviation & Value & Value \\
\hline Communicat & 1.00 & 277 & 98.38 & 11.40 & 64.00 & 131.00 \\
\cline { 2 - 7 } ion Skill & 2.00 & 59 & 100.22 & 14.17 & 71.00 & 133.00 \\
\hline $\begin{array}{c}\text { Democratic } \\
\text { attitude }\end{array}$ & 1.00 & 277 & 66.03 & 4.13 & 53.00 & 80.00 \\
\cline { 2 - 7 } & 2.00 & 59 & 65.36 & 4.59 & 52.00 & 78.00 \\
\hline
\end{tabular}


When Table 3 is examined, it is seen that the mean of communication skill scores of female prospective teachers is $\bar{X}=98.38$, the mean of communication skill scores of male prospective teachers is $\bar{X}=100.22$. When the mean scores are examined, both male and female prospective teachers' communication skills can be considered to be low.

When Table 3 is examined, it can be seen that the mean of the democratic attitude scores of female prospective teachers is $\bar{X}=66.03$, and the mean of the democratic attitude scores of the male prospective teachers is $\bar{X}=65.36$. When the mean scores are examined it can be concluded that the democratic attitude scores of both male and female prospective teachers are low.

Table 4. Box M Test Results for Gender Variable

\begin{tabular}{|c|c|}
\hline Box's M & 6.605 \\
F & 2.173 \\
Sd1 & 3 \\
Sd2 & $145,457.506$ \\
Sig. & 0.089 \\
\hline
\end{tabular}

When Box $M$ test results are examined in Table 4, it is seen that the covariances of dependent variables are equal throughout the groups for the gender variable. $(p>0.05)$

Table 5. Levene F Test Results for Gender Variable

\begin{tabular}{|c|c|c|c|c|}
\hline & $\mathrm{F}$ & $\mathrm{sd} 1$ & $\mathrm{sd} 2$ & $\mathrm{P}$ \\
\hline Communication Skill & 3.560 & 1 & 341 & 0.060 \\
Democratic attitude & 0.621 & 1 & 341 & 0.431 \\
\hline
\end{tabular}

When the results of the Levene $\mathrm{F}$ test are examined in Table 5, it is observed that the variance of the scores of the dependent variable is equal for each group of gender variable $(p>0.05)$.

Table 6. Wilk's Lambda Results in terms of Gender Variable

\begin{tabular}{|c|c|c|c|c|c|c|}
\hline Effect & Value & $\mathrm{F}$ & Hypothesis sd & Error sd & $\mathrm{p}$ & $\eta^{2}$ \\
\hline $\begin{array}{c}\text { Wilk's } \\
\text { Lambda }\end{array}$ & 0.991 & $1.455^{\mathrm{b}}$ & 2.000 & 333.000 & 0.235 & 0.009 \\
\hline
\end{tabular}

Wilk's Lambda results showed that the scores obtained from the linear component of communication skills and democratic attitude variables did not show any significant difference according to gender ( $p>0.05$ ).

Table 7. One way MANOVA test results according to gender variable

\begin{tabular}{|cc|c|c|c|c|c|}
\hline Error source & Dependent variable & Sum of squares & Sd & F & $\mathrm{p}$ & $\eta^{2}$ \\
\hline \multirow{2}{*}{ Model } & Communication Skill & 164.258 & 1 & 1.154 & 0.283 & 0.003 \\
& Democratic attitude & 22.027 & 1 & 1.240 & 0.266 & 0.004 \\
\hline \multirow{2}{*}{ Gender } & Communication Skill & 164.258 & 1 & 1.154 & 0.283 & 0.003 \\
& Democratic attitude & 22.027 & 1 & 1.240 & 0.266 & 0.004 \\
\hline \multirow{2}{*}{ Error } & Communication Skill & $47,535.572$ & 334 & & & \\
& Democratic attitude & 5933.294 & 334 & & & \\
\hline \multirow{2}{*}{ Total } & Communication Skill & $3,321,263.000$ & 336 & & & \\
\end{tabular}

When the MANOVA results were examined, it was seen that there was no significant difference between the communication skills and the democratic attitude scores of the prospective teachers in relation to gender $(\mathrm{p}>0.05)$.

Research Problem 3: Is there a meaningful difference according to the variable of the subject of license (the area that they specialize in)

Table 8. Descriptive Statistics in Terms of Subject of License Variable

\begin{tabular}{|c|c|c|c|c|c|c|}
\hline \multicolumn{2}{|c|}{} & $N$ & $\bar{X}$ & Std. Deviation & Minimum Value & Maximum Value \\
\hline \multirow{4}{*}{ Communication Skill } & 1.00 & 133 & 99.37 & 11.34 & 74.00 & 129.00 \\
\cline { 2 - 7 } & 2.00 & 76 & 101.24 & 13.31 & 64.00 & 130.00 \\
\cline { 2 - 7 } & 3.00 & 61 & 96.92 & 11.88 & 77.00 & 133.00 \\
\cline { 2 - 7 } & 4.00 & 66 & 96.11 & 10.95 & 67.00 & 125.00 \\
\hline \multirow{5}{*}{ Democratic attitude } & 1.00 & 133 & 65.49 & 3.96 & 52.00 & 80.00 \\
\cline { 2 - 7 } & 2.00 & 76 & 66.78 & 4.70 & 53.00 & 77.00 \\
\cline { 2 - 7 } & 3.00 & 61 & 66.53 & 4.27 & 57.00 & 78.00 \\
\cline { 2 - 7 } & 4.00 & 66 & 65.20 & 3.91 & 57.00 & 75.00 \\
\hline
\end{tabular}


When Table 8 is examined, it is seen that the mean of communication skill scores of prospective teachers in primary school teacher department is $\bar{X}=99.37$, the mean of communication skill scores of the prospective teachers in pre-school teacher department is $\bar{X}=101.24$, the mean of communication skills scores of prospective science teachers is $\bar{X}=96.92$ and the mean of communication skill scores of the prospective social studies teachers is $\bar{X}=$ 96.11. When the mean scores are examined, the communication skills of all prospective teachers can be considered to be low.

When Table 8 is examined, it can be seen that the mean of democratic attitude scores of the prospective teachers in primary school teacher department is $\bar{X}=65.49$, the mean of democratic attitude scores of the prospective teachers in the preschool teacher department is $\bar{X}=66.78$, the mean of democratic attitude scores of the prospective science teachers is $\bar{X}=66.53$ and the mean of democratic attitude scores of the prospective social sciences teachers is $\bar{X}=$ 65.20. When the mean scores are examined it can be concluded that the democratic attitude scores of both male and female prospective teachers are low.

Table 9. Box M Test Results for Subject of License Variable

\begin{tabular}{|c|c|}
\hline Box's M & 7.655 \\
F & 0.840 \\
df1 & 9 \\
df2 & $550,596.797$ \\
Sig. & 0.579 \\
\hline
\end{tabular}

When Box M test results are examined in Table 9, it is seen that the covariances of dependent variables are equal throughout the groups of license variable $(p>0.05)$
Table 10. Levene F Test Results for Subject of License Variable

\begin{tabular}{|c|c|c|c|c|}
\hline & $\mathrm{F}$ & $\mathrm{sd} 1$ & $\mathrm{Sd} 2$ & $\mathrm{P}$ \\
\hline Communication Skill & 0.876 & 3 & 332 & 0.454 \\
Democratic attitude & 1.253 & 3 & 332 & 0.290 \\
\hline
\end{tabular}

When the results of the Levene $F$ test are examined in Table 10, it is observed that the variance of the scores of the dependent variable is equal for each group of gender variable $(\mathrm{p}>0.05)$.

Table 11. Wilk's Lambda Results in terms of Subject of License Variable

\begin{tabular}{|c|c|c|c|c|c|c|}
\hline Effect & Value & $\mathrm{F}$ & Hypothesis sd & Error sd & $\mathrm{P}$ & $\eta^{2}$ \\
\hline $\begin{array}{c}\text { Wilk's } \\
\text { Lambda }\end{array}$ & 0.955 & 2.569 & 6.000 & 662.000 & 0.018 & 0.023 \\
\hline
\end{tabular}

Wilk's Lambda results showed that the scores obtained from the linear component of communication skills and democratic attitude variables show a significant difference according to subject of license variable $(p>0.05)$ When eta-squared effect size value is examined, it showed the subject of license variable has a medium level effect on the scores obtained from the linear component of communication skills and democratic attitude variables.

When the MANOVA results were examined, it is seen that the communication skill scores have a meaningful difference according to subjects of license $(p<0.05)$ and eta-square effect size has a value of $\eta^{2}=0039$. These findings show that the subject of license variable has a medium level effect on the communication skills of prospective teachers. Tukey test, which is one of the multiple comparison tests, was conducted in order to determine which subject of license creates this difference between the scores of communication. The test result showed that the difference is between 2 to 4 , and is more in favor of 2. It was found that there is no meaningful difference between the democratic attitude scores in relation to subjects of license $(p>0.05)$.

Table 12. One way MANOVA test results according to subject of license variable

\begin{tabular}{|cc|c|c|c|c|c|}
\hline Error source & Dependent variable & Sum of squares & Sd & F & p & $\eta^{2}$ \\
\hline \multirow{2}{*}{ Model } & Communication Skill & 1186.298 & 3 & 2.822 & 0.039 & 0.025 \\
& Democratic attitude & 137.238 & 3 & 2.610 & 0.051 & 0.023 \\
\hline \multirow{2}{*}{ Gender } & Communication Skill & 1186.298 & 3 & 2.822 & 0.039 & 0.025 \\
& Democratic attitude & 137.238 & 3 & 2.610 & 0.051 & 0.023 \\
\hline \multirow{2}{*}{ Error } & Communication Skill & $46,513.532$ & 332 & & & \\
& Democratic attitude & 5818.083 & 332 & & & \\
\multirow{2}{*}{ Total } & Communication Skill & $3,321,263.000$ & 336 & & & \\
& Democratic attitude & $1,465,614.000$ & 336 & & & \\
\hline
\end{tabular}




\section{Discussion}

In this study, the relationship between the democratic attitude of prospective teachers and their communication skills was examined. It was examined if there is a significant difference between the prospective teachers' democratic attitude and communication skills depending on the factors of gender and subject of license (the area that they specialize in). It was found that there is a significant positive correlation at a low level between the communication skills and democratic attitude of prospective teachers. It was determined that there is no significant difference depending on gender neither for the scores of democratic attitudes nor for the scores of the communication skills of prospective teachers. It was found that there is a significant difference between communication scores of prospective teachers depending on their subject of license (the area that they specialize) It was found that the subject of license variable has a medium level of correlation on the communication skills of prospective teachers. On the other hand, it was found that subject of the license has no significant correlation on the democratic attitude scores.

The existence of a positive correlation between communication skills and democratic attitudes of prospective teachers, even though at a low level, still shows that there is a relation between communication skills and democratic attitudes. This finding supports the findings of the research conducted by [6]. In this research where the creative drama instructors' communication skills and democratic attitudes were examined, it was determined that there is a positive correlation between the communication skills and the democratic attitude. [30] also determined in his study of "determination of the relationship between new media literacy, communication skills and democratic tendency with structural equation model" that communication skill positively affect the critical media consumption and democratic tendency. Whereas [10] stated that a democratic classroom medium is also a democratic communication medium. According to [12], only a democratic teacher can create a successful communication process in the classroom. The communication skills exhibited in the classroom by the teacher directly affect the democratic values that the students are required to acquire. The communication environment that the teacher creates with his students is very important both in terms of individualization process and developing independent thinking habit.

When the mean scores of communication skills and democratic attitudes of prospective teachers are examined in relation to gender variable, no statistically significant difference was found although mean scores of female prospective teachers for both factors were higher than the male prospective teachers' scores. It was noted that there is no significant difference between communication skills or democratic attitudes of the prospective teachers, in relation to gender. Also in the research conducted by [26], it was found that there is no significant difference between the communication skills and democratic attitudes of creative drama teachers related to gender. This finding supports the results of this study. The findings of the study are important in terms of supporting the idea that the individuals who will conduct the teaching job, regardless of gender, should have the same understanding. In the studies conducted by [24, $31,32,33,22,34.35,8]$ with the aim of determining democratic attitudes of prospective teachers, no significant differences were found between the attitudes of male and female prospective teachers. However, related to gender variable, there are some studies where the democratic attitude scores are more positive in favor of the female teachers and prospective teachers. In the studies conducted by $[23,19,36,15]$, it was determined that there is a significantly positive correlation between democratic attitude in favor of females. Similarly, among the studies conducted to identify communication skills of teachers and prospective teachers, there exist both the ones who found a significant difference between male and female teachers and prospective teachers, as well as the ones who did not find a significant difference. For example, according to the studies made by $[37,21,20,14]$, it was found that female prospective teachers' communication skills are higher than that of the male prospective teachers. On the other hand, in the research conducted by $[38,39,40,11]$, no gender-based significant difference was found between female and male prospective teachers.

It was found that there is a significant difference between communication skill scores of prospective teachers depending on their subject of license (the area that they specialize in). It was found that the subject of license variable has a medium level of correlation on the communication skills of prospective teachers. On the other hand, it was found that subject of the license has no significant correlation on the democratic attitude scores. This difference between the scores of the communication skills of preschool prospective teachers and social studies prospective teachers are found to be in favor of preschool prospective teachers. In the research conducted by [41, 39, $42,14]$, a significant difference in terms of communication skills depending on the department of the prospective teachers was also found. However, in the study conducted by [11], no significant difference of attitudes related to the departments of prospective teachers was found.

\section{Conclusion and Recommendations}

It was found that the level of communication skills and democratic attitude of prospective teachers are low. It was noted that communication skills and democratic attitudes are related to each other however gender variable does not create any difference. It was determined that the subject of license variable has a medium-level correlation on 
communication skill; however, it creates no significant difference in terms of democratic attitude. In the light of these results obtained from the research, the following proposals have been developed: More emphasis should be given to the development of communication skills and democratic attitudes of prospective teachers. In the faculty of education, a communication course is carried out for prospective teachers. In addition to this, education for democracy should be given in order to improve the democratic attitudes of prospective teachers. Research should be conducted on factors affecting the communication skills and democratic attitudes of prospective teachers. The opinions of prospective teachers differ according to their subject of license. For this reason, studies should be done to determine the communication skills and democratic attitudes of the instructors who teach the prospective teachers. Qualitative research can be conducted to provide further in-depth information on this issue.

\section{REFERENCES}

[1] Gündüz,M and Gündüz, F. (2002). Consciousness of Citizenship, An1 Publication Ankara.

[2] Dağı, İ and Polat, N. (2004). Democracy and Human Rights for All. Liberte Publications. Ankara.

[3] Beetham, D.(2006). Democracy and Human Rights (Translated by: Bilal Canatan).Liberte Publications. Ankara.

[4] Barber, B. (1995). Strong Democracy (Translated by: Mehmet Beşikçi).Ayrıntı Publications Istanbul.

[5] Ertürk, S. (1969). Authoritarian Attitude and Democracy, Öğretmen Printing House, Ankara.

[6] Şişman, M. (2006). Democracy and social justice in education: The unchanging myth of the Turkish education system. The Proceedings of New Paradigm Searches in the Turkish Education System, 4-5 November, Ankara. Eğitim-Bir-Sen Publications, 291-305.

[7] Büyükkaragöz, S. (1995). Higher education programs and democratic attitudes. Ankara: Turkish Democracy Foundation Publications.

[8] Elkatmış, M., Toptaş, V.(2015).Examining the Democratic Attitudes of Classroom Teacher Candidates. YYU Journal of Education Faculty, Volume: XII, Issue: I, 128-144.

[9] Duman, T. and Koç, G. (2004). Opinions of Education Faculty Students Regarding Democratic Attitudes and Behaviors of Instructors, XIII. National Educational Sciences Congress, 6-9 July, Inonu University, Malatya.

[10] Çengelci, T. (2011).Place and Importance of Communication in Social Studies. R. Turan. K. Ulusoy (Editor), Foundations of Social Studies (p. 206-246). Ankara: Pegem Akademi.
[11] Elkatmış, M., Ünalan, E. (2014). A Study on Communication Skill Levels of Classroom Teacher Candidates. Trakya University Journal of Social Sciences. Volume 16 Issue 1 (107-122).

[12] Demirbolat, A. O. (1999).Democracy and Democratic Education. Educational Administration in Theory and Practice. 18(229).

[13] Kontaş, H., Selçuk, H, E., Polat, M. (2016). Examining the Democratic Attitudes of Secondary School Teachers and the Democratic Value Levels of Students. International Journal of Social Sciences. Issue: 44, p. 141-151

[14] Ocak, G., Erşen, Z, B. (2015). Examining Communication Skills Perceptions of Teacher Candidates. Mehmet Akif Ersoy University Journal of Education Faculty, Issue 33, 1 $-19$.

[15] Özdaş, F., Ekinci, A., Bindak, R. (2014). Examining the Attitudes of Teachers Towards Democracy In Terms of Some Variables. Inonu University Journal of Education Faculty. Special Issue / Volume 15, Issue 3, p. 65-81.

[16] Alptekin, A. (2014).Opinions of Primary School Teachers towards the Perception of Democratic School Culture. Canakkale 18 Mart University Institute of Educational Sciences. Unpublished Master's Thesis.

[17] Kaya,C.(2013).Examining the Democratic Attitudes of Classroom Teachers in Classroom Management. Ataturk University. Institute of Educational Sciences. Unpublished Master's Thesis.

[18] Telatar, S. (2012).Examining the Relationship between Democratic Attitudes and Personality Traits of Elementary School Teachers: Example of Istanbul Anatolian Side. Yeditepe University Social Sciences Institute. Unpublished Master's Thesis.

[19] Gömleksiz, M. N., Çetintas, S. (2011). Democratic Attitudes of Teacher Candidates. (Firat, Dicle, December 7, Examples of Cumhuriyet and Erzincan Universities). Dicle University Journal of Ziya Gokalp Education Faculty.17, $1-14$.

[20] Çuhadar, C., Özgur, H., Akgün, F., Gündüz, S. (2014). Communication Skills and Communication Ways of Teacher Candidates. Ahi Evran University Journal of Kirsehir Education Faculty. Volume 15, Issue 1, Pages 295-311.

[21] Durukan, E., Maden, S. (2010).A Study on the Communication Skills of Turkish Teachers. Journal of Social Sciences Research, 1, 59-74.

[22] Yilmaz, K.(2009).Examining the Democratic Attitudes of Classroom Teachers in terms of Perceived Attitudes of Parents and Some Demographic Variables. Maltepe University Social Sciences Institute. Unpublished Master's Thesis.

[23] Genç, S. Z. and Kalafat, T. (2008). A Study on Evaluating the Democratic Attitudes and Empathic Skills of Teacher Candidates, Manas University Journal of Social Sciences, Issue: 19, 211-222.

[24] Bulut, N. (2006). Relations between the democratic attitudes of a group of university students and various variables. Educational Administration in Theory and 
Practice, 45, 37-59.

[25] Saracaloğlu, A.S, Evin, İ. and Varol, R. (2004). A comparative study on the democratic attitudes of teachers working in various institutions in İzmir and teacher candidates. Journal of Educational Sciences in Theory and Practice, 4(2), 335-363.

[26] Soylu, S. (2017).Examining the Relationship between Communication Skills and Democratic Attitudes of Creative Drama Instructors. Ankara University Institute of Educational Sciences. Unpublished Master's Thesis.

[27] Büyüköztürk, Ş., Çakmak, E. K., Akgün, Ö. E., Karadeniz, S., Demirel, F. (2008). Scientific Research Methods. Pegem Akademi. Ankara.

[28] Gözütok, D. (1995) Democratic Attitudes of Teachers. Turkish Democracy Foundation Publications, Ankara.

[29] Ersanl1, K., Balc1, S. (1998), "Developing the communication skills inventory: Study of validity and reliability", Journal of Turkish Psychological Counseling and Guidance, 2, 7-12.

[30] Barut, E. (2015).New Media Literacy, Communication Skills and Democratic Tendency: Structural Equation Modeling. Suleyman Demirel University. Institute of Educational Sciences. Unpublished Master's Thesis.

[31] Karahan, T. F., Sardogan, M. E., Ozkamali, E. and Dicle, A. N. (2006). Democratic Attitudes of Teacher Candidates, Neurotic Trends and Self Realization, Hacettepe University Journal of Education Faculty, 30, 149-158.

[32] Ercoşkun, M. H. and Nalçacı, A. (2008). Examining the Empathic Skills and Democratic Attitudes of Classroom Teacher Candidates. Journal of National Education, 180, 204-215.

[33] Koç,Y.(2008).Determining the Democratic Attitudes of Physical Education Teachers and Comparing These Attitudes in terms of Various Variables. Abant Izzet Baysal University Social Sciences Institute. Unpublished Master's Thesis.
[34] Evcimik, S.C. (2009).Democratic Attitudes of Education Faculty Students.(Firat, Dicle, December 7, Examples of Cumhuriyet and Erzincan Universities).Firat University. Institute of Social Sciences Unpublished Master's Thesis.

[35] Kurnaz, A. (2011).Evaluating the Relationship between Creativity Levels and Democratic Attitudes of Elementary School Teachers. Kahramanmaras Sutcu Imam University. Social Sciences Institute. Unpublished Master's Thesis.

[36] Üstün, G. (2011).Examining the Relationship between Reflective Thinking Tendencies and Democratic Attitudes of Classroom Teachers. Marmara University. Institute of Educational Sciences. Unpublished Master's Thesis.

[37] Tekin, M., Yıldız. M., Lök, S., Taşğın, O. (2009). Examining the Democratic Attitude Levels of Teacher Candidates Studying in School of Physical Education and Sports in terms of Various Variables. Nigde University Journal of Physical Education and Sports Sciences. Volume 3, Issue 3, 204-212.

[38] Pehlivan, K. B. (2005).A Study on the Communication Skills Perceptions of Teacher Candidates. Ilkögretim-Online, 4(2), 17-23.

[39] Dilekmen, M., Başçı, Z. and Bektaş, F. (2008). Communication Skills of Education Faculty Students. Ataturk University Journal of Social Sciences Institute, 12(2), 223-231.

[40] Saracaloğlu, A, S., Yenice, N, Karasakaloğlu, N. (2009)."Relationship between Communication and Problem Solving Skills, and Interests and Habits of Teacher Candidates", Yuzuncu Yil University Journal of Education Faculty, Volume 6, Issue 2, p.186-206.

[41] Güven, A. and Yalçınkaya-Akyüz, M. (2001).Opinions of Teacher Candidates on Communication and Problem Solving Skills. Ege Journal of Education, 1, 13-22.

[42] Gülbahçe, O. (2010).Examining the Communication Skills of K.K Education Faculty Students Journal of Ataturk Physical Education and Sports Sciences, 12(2), 12-22. 